\title{
Penanaman Nilai Spiritual dalam Dimensi Psikoterapi Islam di PP. Rehabilitasi Salafiyah Syafi'iyah Nashrun Minallah
}

\author{
Desi Alawiyah $^{1}$, Iin Handayani ${ }^{2}$ \\ ${ }^{1}$ Universitas Islam Negeri Raden Intan Lampung \\ ${ }^{2}$ Universitas Islam Negeri Sunan Kalijaga Yogyakarta \\ Email Address: alawiyahdesi2@gmail.com
}

Submitted: 2019-03-17, Revised: 2019-03-17, Accepted: 2019-06-25

\begin{abstract}
The search for meaning of life can be achieved by using the dimension of spirituality to fulfill the inner needs of humans. This study was intended to describe the spiritual values instilled by the coaches of Nashrun Minallah Islamic Boarding School to students who experienced mental disorders, especially those affected by magic and genie disorders through Islamic psychotherapy. This article uses a type of qualitative research, the method of collecting data through observation, interviews and documentation, with analytical techniques using data reduction, presentation of data and drawing conclusions. The results of the study that the spiritual form shown by santri leads to positive spiritual products includes a more meaningful life, more active worship and a balance between fulfilling life in the world and in the hereafter according to the guidance of the Qur'an and as-Sunnah. The form of Islamic psychotherapy that is practiced is the therapy of prayer, dhikr and ruqyah so that someone is spared from interference from spirits.
\end{abstract}

Keywords: Spiritual Value; Islamic Psychotherapy

\begin{abstract}
Abstrak: Pencarian makna hidup dapat diraih dengan menggunakan dimensi spiritualitas demi memenuhi kebutuhan batin manusia. Penelitian ini dimaksudkan untuk menggambarkan nilai spiritual yang ditanamkan pembina Pondok Pesantren Nashrun Minallah kepada santri yang mengalami gangguan mental khususnya pada mereka yang terkena gangguan sihir dan jin melalui psikoterapi Islam. Artikel ini menggunakan jenis penelitian kualitatif, metode pengumpulan data melalui observasi, wawancara dan dokumentasi, dengan teknik analisis menggunakan reduksi data, penyajian data dan penarikan kesimpulan. Hasil penelitian bahwa bentuk spiritual yang ditunjukkan santri mengarah pada produk spiritual positif mencakup hidup yang lebih bermakna, ibadah lebih giat dan adanya keseimbangan antara pemenuhan kehidupan di dunia dan di akhirat sesuai dengan tuntunan Alquran dan as-Sunnah. Adapun bentuk psikoterapi Islam yang diamalkan yaitu terapi salat, dzikir dan ruqyah agar seseorang terhindar dari gangguan makhluk halus.
\end{abstract}

Kata kunci: Nilai Spiritual; Psikoterapi Islam

\section{Pendahuluan}

Pengamatan terhadap kondisi masyarakat di Indonesia banyak didapati, sedang mengalami mental yang tidak sehat. Data WHO menunjukkan dari tahun terakhir, sedikitnya ada 50 ribu orang Indonesia melakukan bunuh diri akibat kemiskinan dan himpitan ekonomi. Faktor ekonomi ini, membuat seseorang menjadi rentan terhadap stress, cemas, ketergantungan pada zat psikoaktif serta berperilaku menyimpang. Riset dasar kesehatan nasional tahun 2007 juga menyebutkan sekitar satu juta orang di Indonesia mengalami gangguan jiwa berat, sedang 19 juta orang lainnya menderita gangguan jiwa ringan hingga sedang. Artinya 14,1\% penduduk Indonesia mengalami gangguan jiwa dari yang ringan hingga berat. Kondisi ini semakin diperberat melalui aneka bencana alam yang terjadi di hampir seluruh wilayah Indonesia(Qodariah, 2015).

Berdasarkan survei dari Nation Intitute for Health Care Research di Amerika menunjukkan bahwa $70 \%$ dari populasi pasien yang diteliti menginginkan kebutuhan spiritual mereka dilayani sebagai bagian dari pelayanan medis. Survei lain menunjukkan bahwa 91\% dokter melaporkan bahwa pasien mereka mencari bantuan spiritual dan kerohanian untuk membantu menyembuhkan penyakitnya. Kebutuhan pasien akan spiritual ini juga dikuatkan 
oleh Abernethy dalam penelitian yang berjudul "Psychoneuroimmunology, Spirituality and Medicine", dimana terapi psikoreligius memegang peranan penting sebagai faktor psikologis yang bersifat positif dan juga adanya hubungan positif antara kekebalan tubuh dengan spiritualitas(Susanto, 2014).

Banyak cara dilakukan untuk mengatasi keadaan mental yang tidak sehat tersebut, baik secara medis maupun non medis. Sebagian orang banyak yang berkonsultasi kepada Psikolog, Psikiater bahkan ke rumah sakit. Banyak juga yang berkonsultasi kepada orang pintar atau melakukan pengobatan alternatif lainnya. Salah satu cara yang islami untuk mengobati orang yang tidak sehat mental adalah dengan kembali pada Alquran dan hadits Rasulullah, sebagaimana Alquran berbicara rasio dan kesadaran manusia. Alquran juga menunjukkan kepada manusia jalan terbaik dalam kehidupan pribadi maupun sosial, aktualisasi diri, pengembangan kepribadian yang kemudian mengantarkan seseorang pada jenjang ketenangan jiwa agar tercapai kebahagiaan dunia dan akhirat.

Ketenangan jiwa dan kebahagiaan hidup merupakan kebutuhan pokok yang mendorong atau memotivasi seseorang dalam melakukan aktivitas untuk hidup yang lebih bermakna. Hidup yang bermakna dalam hal ini dapat disejajarkan dengan mereka yang senantiasa telah tawazun (seimbang) dalam pemenuhan kehidupannya di dunia dan di akhirat melalui penanaman nilai dan spiritual yang disertai keyakinan terhadap agama.

Semakin maraknya berbagai terapi alternatif yang menjanjikan problem solving menunjukkan betapa besar kepercayaan masyarakat Indonesia terhadap model psikoterapi Islam tersebut. Hidup dengan berlandaskan religiusitas akan memberikan kekuatan jiwa bagi seseorang untuk menghadapi masalah serta menimbulkan sikap rela menerima kenyataan. Penelitian ini dimaksudkan untuk menggambarkan nilai dan spiritual yang ditanamkan pembina Pondok Pesantren Nashrun Minallah kepada santri yang mengalami gangguan mental khususnya pada mereka yang terkena gangguan sihir dan jin melalui psikoterapi Islam dengan mengevaluasi keefektifan terapi salat, dzikir dan ruqyah dalam menangani kasus tersebut.

\section{Metode Penelitian}

Jenis penelitian ini menggunakan deskriptif kualitatif, yaitu prosedur penelitian yang menghasilkan data deskriptif berupa kata-kata tertulis atau dari lisan orang-orang dan perilaku yang diamati atau dalam hal ini pendekatan diarahkan pada latar belakang objek dan individu tersebut secara holistik(Moleong, 2006). Metode ini juga diartikan sebagai prosedur atau cara memecahkan masalah penelitian dengan memaparkan keadaan objek yang diselidiki (seseorang, lembaga, masyarakat dan lain-lain) sebagaimana adanya berdasarkan fakta-fakta yang aktual(Martini \& Nawawi, 1995).

Ada tiga unsur penting yang harus dipertimbangkan dalam menetapkan lokasi penelitian yaitu tempat, pelaku dan kegiatan(Nasution, 1996). Penelitian tentang penanaman nilai spiritual dalam dimensi psikoterapi Islam di PP. Rehabilitasi Salafiyah Syafi'iyah Nashrun Minallah berlokasi di Krapyak Wetan RT 13 RW 56 Panggungharjo Sewon Bantul Yogyakarta. Pendekatan penelitian ini diarahkan sebagai pengungkapan pola pikir peneliti dalam menganalisis sasarannya atau dalam ungkapan lain pendekatan ialah disiplin ilmu yang dijadikan acuan dalam menganalisis objek yang diteliti sesuai dengan logika ilmu itu. Pendekatan yang digunakan yaitu pendekatan bimbingan dan konseling. Sumber data primer dalam penelitian ini adalah Ust. Yoyok selaku pembina di PP. Nashrun Minallah. Sumber data sekundernya yaitu buku, jurnal, internet dan dokumentasi. Metode pengumpulan data berupa observasi, wawancara dan dokumentasi. Langkah-langkah yang digunakan dalam menganalisis data pada penelitian melalui reduksi data, penyajian data dan penarikan kesimpulan. 


\section{Hasil dan Pembahasan}

1. Gambaran Umum Pondok Pesantren Nashrun Minallah

Pondok Pesantren Rehabilitasi Salafiyah Syafi'iyah Nashrun Minallah atau lebih dikenal dengan Pondok Pesantren Nasrun Minallah didirikan oleh Ustadz R Yoyok. Pesantren ini mengamalkan tradisi Nahdhatul Ulama seperti umumnya pesantren salafiyah syafi'iyah. Dahulu pesantren ini bernama Darul Ilmi yang giat melakukan pengkaderan pemuda-pemudi Islam di wilayahnya, pesantren ini juga merupakan tempat penyembuhan bagi orang-orang yang terkena gangguan Jin dan Stress. Pondok ini dibangun berawal dari keprihatinan tentang kemerosotan moral dikalangan remaja diwilayah Krapyak Wetan. Saat ini pondok pesantren Nashrun Minallah masih istiqomah mengkader generasi muda Krapyak Wetan agar menjadi manusia yang mulia.

Pondok Pesantren Nasruminallah dalam menjalankan dakwah dan Ruqyah tidak mematok tarif, hanya menyediakan kotak infaq yang bisa diisi secara sukarela untuk kegiatan dakwah. Salah satu kegiatan rutin pondok Pesantren Nashrun Minallah adalah kajian Ahad Legi setiap pukul 06.30-08.00 yang pesertanya adalah masyarakat umum. Rangkaian kegiatan yang dilakukan yaitu syiir tanpo waton Gusdur, sholat dhuha, dzikir pagi Alma'surat, doa-doa kemudian kajian sampai selesai.

2. Psikoterapi Islam

Psikoterapi merupakan pengobatan yang dilakukan pada rana psikologis seseorang untuk menangani masalah yang berorientasi pada perasaan, pikiran dan perilaku individu. Psikoterapi terdiri dari dua kata yaitu kata "Psyche" yang artinya jiwa, mental atau pikiran dan kata "Therapy" yang berarti pengobatan, penyembuhan atau perawatan. Psikoterapi juga disebut dengan istilah terapi mental, terapi kejiwaan atau terapi pikiran(Kusuma, 2017).

James P.Chaplin dalam hal ini mengelompokkan pengertian psikoterapi menjadi dua bagian. Secara khusus, bahwa psikoterapi sebagai penerapan khusus terhadap teknik penyembuhan penyakit mental dalam menghadapi kesulitan mengenai penyesuaian diri dalam kehidupan sehari-hari. Secara umum bahwa cakupan psikoterapi terkait penyembuhan melalui keyakinan keagamaan dengan menggunakan pembicaraan informal atau dalam hal ini menyangkut diskusi personal dengan teman ataupun guru (Chaplin, 1999). Lebih spesifik bahwa psikoterapi Islam merupakan proses penyembuhan suatu penyakit, baik psikis, fisik, spiritual dan moral melalui bimbingan dan pencerahan yang berlandaskan pada Alquran dan Hadis(Adz-Dzaky \& Bakran, 2002).

Orang-orang yang mengalami gangguan jiwa diasumsikan mendapatkan gangguan dari luar dirinya, semacam gangguan dari roh halus. Pada tahapan magis dukun-dukun atau shaman menjadi ahli-ahli kejiwaan yang akan memberikan penanganan pada penderita gangguan tersebut, karena orang yang mengalami gangguan jiwa pada tahapan ini dianggap mendapat gangguan roh halus, jin atau setan(Naan, 2018).

Penelitian ini berfokus pada psikoterapi Islam yang merupakan suatu terapi dengan tujuan untuk kembali mempelajari dan senantiasa mengamalkan ajaran Islam, karena telah kita ketahui bersama bahwasannya tuntunan dalam ajaran Islam berdasar kepada Alquran dan as-Sunnah yang terkait dengan doa-doa, permohonan ampunan agar kehidupan manusia diberi kesejahteraan, ketenangan, keselamatan dunia dan akhirat. Jenis terapi dalam proses penyembuhan yang dilakukan oleh Ust. Yoyok sesuai dengan anjuran yang ada dalam ajaran Islam seperti diadakannya proses salat, dzikir dan ruqyah.

a. Salat 
Salat dalam agama Islam menempati kedudukan yang tidak dapat ditandingi oleh ibadah lainnya karena merupakan tiang agama. Sabda Rasulullah saw bahwa "Kepala setiap perkara ialah Islam, sedangkan tiangnya ialah salat dan puncaknya adalah berjuang di jalan Allah" (HR.Tirmidzi). Bagi orang muslim salat bukan hanya dilihat sebagai suatu kewajiban melainkan kebutuhan mendasar bagi kehidupan. Banyak makna yang dapat dipelajari dari setiap gerakan shalat, mulai dari berdiri, mengucapkan takbir, rukuk, iftidal, sujud dan salam. Seorang muslim yang benar-benar menghayati salatnya dengan ikhlas, tuma'ninah dan khusyuk akan tenang dan terhindar dari kegelisahan, kecemasan, depresi dan lain sebagainya(Zaini, 2015).

Hal ini yang menjadi landasan mengapa Ust. Yoyok menerapkan metode salat dalam pengobatannya, agar siapapun yang mengerjakannya akan mendapatkan ketenangan jiwa jika pelaksanaannya pada tingkatan yang khusyuk, sebagaimana diriwayatkan dari sahabat Hudzaifah r.a. bahwa dia telah berkata "Jika Nabi saw merasa gundah karena sebuah perkara, maka beliau akan menunaikan salat" (HR. Abu Daud). Hubungan seseorang dengan Tuhannya ketika salat akan menghasilkan kekuatan spiritual sangat besar yang berpengaruh pada perubahan penting dalam fisik dan psikisnya. Kekuatan spiritual ini seringkali menghilangkan stres, menyingkirkan kelemahan dan menyembuhkan berbagai penyakit.

b. Dzikir

Kata dzikir berasal dari bahasa Arab az-zikr yang berarti mengisyaratkan, mengagungkan, menyebut atau mengingat-ingat. Adapun secara istilah dzikir diartikan sebagai ucapan lisan, gerakan raga maupun getaran hati sesuai dengan tuntunan Islam dalam rangka mendekatkan diri kepada Allah swt. Dalam kaitannya dengan dzikrullah, dzikir berarti mengingat dan menyebut Asma Allah. Ingat adalah gerak hati, sedangkan sebutan adalah gerakan lisan. Dzikir yang baik adalah perpaduan antara dzikir hati dan dzikir lisan sebagaimana hati mengingat Allah dan lisan menyebutnya. Dalam artikelnya, Rofiqoh menuliskan bahwa Imam Nawawi di dalam kitabnya menjelaskan pengertian dzikir secara universal, yaitu dzikir yang tidak hanya pada ucapan tasbih, tahlil, tahmid, takbir tetapi setiap orang yang beramal karena Allah dengan ketaatan maka ia termasuk orang yang berdzikir. Aidh Abdullah Al-Qarny juga menambahkan bahwa para ulama membagi dzikir menjadi tiga kategori yakni: dzikir dengan hati dan lisan, dzikir dengan hati tanpa lisan, dzikir dengan lisan tanpa hati(Rofiqah, 2017).

Ungkapkan Ust. Yoyok bahwa pada prinsipnya dzikir bertujuan untuk kembali mengingat dengan senantiasa menyebut asma Allah yang kemudian akan membentuk pribadi yang sehat karena telah mendapatkan ketenangan dari proses dzikir yang dilakukan, sehingga hal tersebut menumbuhkan nilai spiritualitas dalam diri seseorang.

c. Ruqya

Pemberian terapi ruqyah syar'iyyah adalah dengan menggunakan ayat-ayat dalam Alquran dengan membaca, mendengarkan secara keseluruhan ataupun sebagian ayat tertentu yang ada hubungannya dengan permasalahan atau gangguan suatu penyakit. Seseorang yang diruqyah artinya sudah dimohonkan perlindungan kepada Allah, menggunakan asma'ul husna dan surat-surat mu'awidzat (penangkal keburukan)(Qodariah, 2015).

Salah satu kriteria santri di PP. Nasrun Minallah adalah pasien penderita kesurupan. Menurut Ust.Yoyok kesurupan merupakan salah satu jenis penyakit yang dialami oleh seseorang diiringi dengan ketegangan pada seluruh anggota tubuh, ada yang berteriak, menangis, kadang-kadang bertindak kasar, terjadi perubahan suara yang tadinya halus menjadi besar dan berat, terjadi pertambahan tenaga dari kondisi normal, berlarian tidak tentu arah, menyakiti orang disekitarnya bahkan tidak jarang menyebabkan ada pasien yang 
pingsan. Jin mengendalikan diri manusia yang pengaruhnya terbawa pada akal pikiran, indra dan organ tubuh dengan beragam cara yang terkadang bisa berupa kelumpuhan beberapa anggota badan.

Faktor yang memengaruhi terjadinya gangguan jin dapat ditinjau dari dua perspektif yaitu agama dan psikologi. Sigmund Freud dalam perspektif psikologi menyatakan bahwa kesurupan dalam hal ini sama halnya dissosiasi yang merupakan salah satu bentuk deffence mechanism ego ketika kebutuhan-kebutuhan id tidak tersalurkan karena adanya superego. Orang yang mengalami stres berat atau kejadian traumatik, coping stress, tidak dapat mengatasi stressor yang ada sehingga ego melemah, ia mulai melakukan pertahanan diri dalam bentuk dissosiasi, yaitu kehilangan kemampuan mengingat peristiwa yang terjadi pada dirinya. Dalam perspektif Islam, gangguan jin biasanya terjadi pada orang yang mengalami kondisi takut yang berlebihan, marah yang tidak tertahankan, sedih yang mendalam, kelalaian dan mengikuti nafsu syahwat(Susanto, 2014).

Kepercayaan dan budaya turun temurun fenomena kesurupan masih diyakini sebagai suatu kondisi gangguan perilaku yang disebabkan oleh masuknya semacam makhluk dari golongan jin atau setan ke dalam tubuh seseorang, sehingga pengobatannya pun masih menggunakan cara-cara mistis, seperti menggunakan bawang putih, jeruk nipis, serta air yang telah diberi mantera-mantera atau dengan cara menekan anggota bagian tubuh yang diyakini tempat masuknya setan seperti ujung ibu jari kaki, ujung ibu jari tangan, kemudian bagian sendi lutut, sendi siku, bagian leher, ubunubun(Pasmawati, 2018). Sehubungan dengan hal tersebut Ust. Yoyok menambahkan bahwasannya jin bisa tinggal di cincin yang dipakai oleh seseorang kemudian masuk melalui jari. Penyembuhannya bisa melalui ruqya dengan pembacaan ayat-ayat suci Alquran ataupun dengan meminum air yang telah dibacakan ayat-ayat-Nya.

Waliyun Arifuddin dalam tulisan Asy Syahawi bahwa ruqya sebaiknya ditempuh melalui prosedur-prosedur terapi seperti: Pengenalan ruqyah syar'iyah yang meliputi sumber syariat dan penanaman nilai-nilai, kontrak pertemuan terapi sehingga dapat diatur kapan pelaksaan terapi dilakukan, pengkondisian tempat dan pasien, dialog tentang materi keislaman, pembacaan ayat-ayat ruqyah. Ruqyah menggunakan ayat-ayat Alquran. Dari sini ada asumsi bahwa ayat Alquran memiliki energi yang dapat memberikan efek psikoterapi terhadap penderita yang mengalami gangguan jiwa maupun kesurupan(AsySyahawi, 2001).

Berdasarkan hasil penelitian melalui wawancara yang telah dilakukan, peneliti menyimpulkan bahwa proses terapi penderita gangguan jin yaitu:

1) Tahap persiapan: Menyiapkan sarana (Alquran, buku dzikir pagi-sore Al-Ma'tsurat, air) dan prasarana berupa tempat tinggal.

2) Tahap pelaksanaan: Sebelum proses terapi dilanjutkan, santri atau pasien PP. Nasrun Minallah dianjurkan untuk melaksanakan salat taubat. Tujuannya agar individu yang melaksanakannya menyesali perbuatan dan berjanji kepada diri sendiri untuk tidak mengulangi perbuatan dosa dan maksiat yang pernah dilakukan. Setelah itu barulah proses terapi dilaksanakan secara individu dan kelompok. Pasien yang mengalami gangguan jin yang berat dengan memberikan ayat-ayat ruqya yang terdapat dalam Alquran. Terapi yang dilaksanakan secara berkelompok dilakukan kepada seluruh santri baik penderita gangguan jin yang ringan maupun berat melalui terapi salat, dzikir, puasa, ruqya massal, dialog keislaman dan penanaman nilai. Waktu pelaksanaanya dilakukan setelah waktu salat, setelah jam kerja pasien, dan biasanya tengah malam ketika pasien melakukan salat malam. 
3) Penutup: Membaca doa dan pemberian sugesti akan kesadaran sebagai makhluk Allah yang senantiasa berserah diri dan mengingatnya dengan tujuan agar dapat bahagia di dunia dan di akhirat.

3. Nilai Spiritual

Proses terapi yang dikemukakan di atas sebenarnya mempunyai tujuan utama yang ingin dicapai yaitu ketenangan jiwa dan pemenuhan kebermaknaan hidup melalui pendidikan spiritual. Pendidikan spiritual dalam hal ini adalah proses penguatan spiritual dan penanaman iman dalam diri santri sebagai bentuk pemenuhan kebutuhan naluriyah beragama mereka, menata sifat mereka dengan tata krama yang baik dan mengarahkan mereka pada nilainilai spiritual yang berlandaskan pada rukun iman dan rukun Islam.

Definisi spiritual setiap individu dipengaruhi oleh budaya, perkembangan, pengalaman hidup, kepercayaan dan ide-ide tentang kehidupan. Spiritualitas juga memberikan suatu perasaan yang berhubungan dengan intrapersonal (hubungan antara diri sendiri), interpersonal (hubungan antara orang lain dengan lingkungan) dan transpersonal (hubungan yang tidak dapat dilihat yaitu suatu hubungan dengan ketuhanan yang merupakan kekuatan tertinggi). Burkhares dalam artikel Mustakim bahwa spiritualitas meliputi aspek yang berhubungan dengan ketidakpastian dalam kehidupan, menemukan arti dan tujuan hidup, menyadari kemampuan untuk menggunakan sumber dan kekuatan dalam diri sendiri, mempunyai perasaan keterikatan dengan diri sendiri dan dengan penciptaNya(Mustakim, 2014).

Nilai spiritual terletak pada kerahasiaan, manusia tidak tahu apakah salatnya diterima atau tidak, apakah puasanya berkualitas dihadapan Allah atau tidak. Kerahasiaan inilah yang menjadi sebab segala sesuatunya hanya milik Allah dan Dialah yang akan membalasnya. Ust. Yoyok mengatakan bahwa mereka yang mengamalkan dzikir secara intens melaporkan terjadinya pengalaman penyembuhan, peningkatan pemahaman dan penghayatan spiritual, merasa bertambah optimis dan lebih tenang, merasa rileks dan stres berkurang, bahkan ada yang setelah keluar dari pesantren ia menjadi seorang pendakwah.

Bahasan penting dalam pendidikan spiritual ini merujuk pada cara dalam menolong mereka yang telah salah dan terlanjur sesat untuk kembali kepada keimanan yang benar dan akidah yang lurus. Hal tersebut dilakukan dengan menyelamatkan mereka dari ikatanikatan keraguan dalam berakidah, penyelamatan mereka dari penyelewengan agama, menjauhkan mereka dari tergelincirnya akhlak-moral, menuntun mereka dalam hal kesabaran, toleransi, dan kasih sayang untuk kembali kepada jalan keimanan dan kebenaran. Pengaruh penting dalam pendidikan spiritual adalah istiqomah yang berarti selalu berusaha mendekatkan diri kepada Allah dengan amar ma'ruf nahi munkar, merasakan eksistensi Allah di setiap waktu dan tempat, menganjurkan dirinya untuk mencari keridhoan-Nya dalam segala perbuatan dan selalu bertawajuh (menghadap) kepada-Nya dengan niat yang tulus, maka dengan hal tersebut kebiasaan untuk tetap istiqomah tertanam dalam dirinya untuk selalu merujuk kepada Alquran dan as-Sunnah(Aslamiah, 2017).

Bidang spiritual adalah bidang yang berkaitan dengan pengembangan potensi rohaniah yang penuh dengan nilai-nilai yang dianggap sakral. Seseorang yang ingin mengembangkan kualitas spiritualnya harus dilandasi dengan keikhlasan, bukan sekadar mencoba-coba. Selain itu, bidang spiritual juga bersifat personal dalam artian bahwa dua orang yang melakukan kegiatan spiritual yang sama akan memiliki hasil yang relatif berbeda. Peningkatan kualitas spiritual tidak dapat diujicobakan. Berangkat dari rumusan konsep diatas, penelitian ini tidak dimaksudkan mengukur spiritualitas seseorang, tetapi hanya berusaha memotret bentuk spiritualitas dari para santri, faktor yang mempengaruhi dan motivasi mereka mengikuti kegiatan.

4. Bimbingan dan Konseling dalam Meningkatkan Nilai dan Spritual 
Spritualitas dalam pencapaiannya tentu membutuhkan sinergi dengan bimbingan dan konseling agar mampu mencapai perkembangan individu dengan melakukan kontrol perilaku diri sendiri sehingga kelak akan tercapai tujuan hidup yang mampu mengintegrasi nilai-nilai kehidupan. Munculnya nilai dan spiritual dalam bimbingan konseling merupakan sesuatu yang tidak terpisahkan dari aspek aqidah. Secara substansial aspek nilai dan spiritual dalam hal aqidah dapat memberikan dua keuntungan besar bagi siapa saja yang melaksanakan ibadah sebagai ritual pengabdiannya kepada Allah swt. Keuntungan tersebut yakni keuntungan ukhrawi dan keuntungan dunia.

Proses bimbingan spiritual yang dilakukan PP. Nasrun Minallah yaitu melalui bimbingan konseling pribadi dan sosial, dalam hal ini pimpinan pondok pesantren memberikan layanan konsultasi kepada santri untuk memberikan dukungan sosial dan empati dalam proses penyesuaian diri. Ust. Yoyok memberikan pemahaman dan penyadaran diri kepada santri terkait dia sebagai mahluk sosial dan mahluk Allah. Pada dasarnya pelaksanaan konseling pribadi dan sosial ini dapat mengacu pada pendekatan PersonCentered dan Terapi Gestalt.

Person-Centered yakni teknik terapi yang berpusat pada klien, teknik ini adalah pembaharuan karena mengasumsikan posisi yang sejajar antara konselor dan pasien atau klien. Hubungan konselor-klien diwarnai kehangatan, saling percaya, klien diperlakukan sebagai orang yang dapat mengambil keputusan sendiri dan bertanggungjawab atas keputusannya. Konselor membantu klien mengenali masalah dirinya sendiri sehingga akhirnya dapat menemukan solusi bagi dirinya sendiri. Pendekatan ini menekankan pada kecakapan klien untuk menentukan isu yang penting bagi dirinya dan pemecahan masalah dirinya. Konsep pokok yang mendasari adalah hal yang menyangkut konsep-konsep mengenai diri (self), aktualisasi diri, teori kepribadian, dan hakekat kecemasan(Mulyadi, 2016).

Terapi kelompok Gestalt yang dimulai dengan initial stage atau tahap perkenalan terlebih dahulu dengan tujuan untuk mencairkan suasana, kemudian merumuskan aturanaturan dalam kelompok yang harus dipatuhi oleh semua anggota agar terapi dapat berjalan dengan lancar dan terarah. Pembina juga memberitahu mengenai tujuan dari terapi dan apa yang ingin dicapai melalui terapi ini, setelah itu, masuk ke transition stage dimana pada tahap ini terapi memberikan psikoedukasi mengenai masalah yang sedang dihadapi. Terapi gestalt dilanjutkan dengan melakukan konfrontasi kepada anggota kelompok untuk memberikan kesadaran bahwa mereka adalah makhluk individu, makhluk sosial dan makhluk Allah. Setelah mereka sadar dan menerima keadaannya, kemudian pembina selaku terapis masuk ke dalam working stage dimana terapis akan mengarahkan anggota untuk membawa kekhawatiran mereka tentang masa depan ke masa sekarang, namun alangkah baiknya, sebelum itu dilakukan Breathing exercise agar udara dapat masuk ke dalam tubuh sehingga oksigen dapat menyebar ke seluruh tubuh sehingga anggota kelompok dapat merasa lebih tenang. Breathing exercise dilakukan secara sederhana yaitu dengan cara menutup mata sambil mengatur pernapasan(Konghoiro, Kartasasmita, \& Subroto, 2018).

Intinya, apabila dikaitkan pengaplikasian bimbingan konseling dan penanaman spiritual maka akan memperoleh nilai positif dari hubungannya dengan Allah, hubungannya dengan sesama manusia dan hubungannya dengan alam yang dapat mengantarkan seseorang untuk hidup yang lebih bermakna. Semua hal ini dapat tercapai jika seseorang baik itu dalam lingkungan keluarga, masyarakat serta komunitas mampu mengintegrasikan peranan bimbingan pribadi-sosial dengan nilai dan spiritual dalam hidup seseorang agar menjadi manusia yang memiliki banyak manfaat serta menebar kebaikan dalam hidupnya. Ust. Yoyok tidak banyak memberikan pemaksaan untuk melaksanakan kegiatan ibadah, melainkan berusaha sedikit demi sedikit dalam mengarahkan dan memberikan sugesti 
positif kepada santri untuk mengamalkan ajaran agama melalui pemahaman religius untuk menigkatkan nilai dan spiritual santri.

Bantuan yang diberikan bertujuan mengarahkan pasien untuk mengoptimalkan potensi spiritual atau religiusnya agar ia mampu menunjukkan respon adaptif atau positif dalam menghadapi penyakitnya. Respon yang adaptif atau positif ini akan memberikan kekuatan yang luar biasa yang mampu mendorong pasien melakukan ketaatan berobat. Seseorang yang mampu memenuhi kebutuhan spiritualnya dengan baik dapat merespon secara positif sakit yang dideritanya, begitupun sebaliknya, seseorang yang tidak mampu memenuhi kebutuhan spiritualnya tidak dapat menerima kondisi sakitnya dan merespon secara negatif sakit yang diderita(Styana, 2016). Ust. Yoyok selalu menyampaikan agar santri tetap sabar dan mengambil hikmah atas apa yang telah terjadi.

\section{Simpulan dan Saran}

Pondok Pesantren Nasrun Minallah didirikan oleh Ustadz R Yoyok yang mengamalkan tradisi Nahdhatul Ulama seperti umumnya pesantren salafiyah syafi'iyah. Penelitian ini berfokus pada psikoterapi Islam yang merupakan suatu terapi dengan tujuan untuk kembali mempelajari dan senantiasa mengamalkan ajaran Islam. Lebih spesifik bahwa psikoterapi Islam merupakan proses penyembuhan suatu penyakit, baik psikis, fisik, spiritual dan moral melalui bimbingan dan pencerahan yang berlandaskan pada Alquran dan Hadis. Jenis terapi dalam proses penyembuhan yang dilakukan sesuai dengan anjuran yang ada dalam ajaran Islam seperti diadakannya proses salat, dzikir dan ruqyah.

Proses terapi tersebut sebenarnya mempunyai tujuan utama yang ingin dicapai yaitu ketenangan jiwa dan pemenuhan kebermaknaan hidup melalui pendidikan spiritual. Nilai spiritual terletak pada kerahasiaan, manusia tidak tahu apakah salatnya diterima atau tidak, apakah puasanya berkualitas dihadapan Allah atau tidak. Proses bimbingan spiritual yang dilakukan PP. Nasrun Minallah yaitu melalui bimbingan konseling pribadi dan sosial, dalam hal ini pimpinan pondok pesantren memberikan layanan konsultasi kepada santri untuk memberikan dukungan sosial dan empati dalam proses penyesuaian diri. Pada dasarnya pelaksanaan konseling pribadi dan sosial ini dapat mengacu pada pendekatan Person-Centered dan Terapi Gestalt.

\section{Daftar Pustaka}

Adz-Dzaky, \& Bakran, M. H. (2002). Konseling dan Terapi Islam. Yogyakarta: Fajar Pustaka Baru.

Aslamiah, S. (2017). Pendidikan Spiritual Sebagai Benteng terhadap Kenakalan Remaja. LEGALITE, 2(I), 95-116.

Asy-Syahawi, M. M. (2001). Pengobatan Rabbani Mengusir Gangguan Jin, Setan, dan Sihir. Bandung: Pustaka Hidayah.

Chaplin, J. P. (1999). Dictionary of Psychology. (K. Kartono, Trans.). Jakarta: Rajawali.

Konghoiro, I., Kartasasmita, S., \& Subroto, U. (2018). Penerapan Group Gestalt Therapy bagi Warga Binaan Lapas Narkotika X yang Mengalami Kecemasan Menjelang Bebas. Jurnal Muara Ilmu Sosial, Humaniora, Dan Seni, 1(2), 430-438.

Kusuma, A. B. (2017). Pendekatan Psychotherapy Alquran dalam Gangguan Kesehatan Mental (Suatu Kajian Psikologi Agama). Journal Al-Manar, 6(1).

Martini, H. M., \& Nawawi, H. (1995). Instrumen Penelitian Bidang Sosial. Yokyakarta: Gajah Mada University. 
Moleong, L. J. (2006). Metodologi Penelitian Kualitatif Edisi Revisi, Cetakan keduapuluh dua, Bandung: PT. Remaja Rosdakarya Offset.

Mulyadi, M. (2016). Penerapan Client Centered Therapy Terhadap Klien "Kk" yang Mengalami Grieving di Sekolah Luar Biasa Negeri A Kota Bandung. Pekerjaan Sosial, 15(1).

Mustakim, H. (2014). Representasi Nilai Spiritual dalam Novel Dzikir dan Pikirkarya Reza Nurul Fajri. Jurnal Nosi, 2(3), 156-157.

Naan, N. (2018). Model Terapi Ibadah dalam Mengatasi Kegersangan Spiritual. Syifa AlQulub, 2(2), 98-107.

Nasution, S. (1996). Metode Penelitian Naturalistik Kualitatif Tarsito. Bandung.

Pasmawati, H. (2018). Fenomena Gangguan Kesurupan (Dalam Perspektif Islam dan Psikologi). EL-AFKAR: Jurnal Pemikiran Keislaman Dan Tafsir Hadis, 7(1), 1-13.

Qodariah, S. (2015). Pengaruh Terapi Ruqyah Syar'iyyah Terhadap Penurunan Tingkat Kecemasan. Scientica, 2(2), 23-37.

Rofiqah, T. (2017). Konseling Religius: Mengatasi Rasa Kecemasan Dengan Mengadopsi Terapi Zikir Berbasis Religiopsikoneuroimunologi Religious Counseling: Overcoming Anxiety with the Adoption of Religiopsikoneuroimunologi Based Remembrance Therapy. KOPASTA: Jurnal Program Studi Bimbingan Konseling, 3(2).

Styana, Z. D. (2016). Bimbingan Rohani Islam dalam Menumbuhkan Respon Spiritual adaptif Bagi Pasien Stroke di Rumah Sakit Islam Jakarta Cempaka Putih. UIN Walisongo.

Susanto, D. (2014). Dakwah melalui Layanan Psikoterapi Ruqyah Bagi Pasien Penderita Kesurupan. Jurnal Bimbingan Konseling Islam, 5(2), 313-333.

Zaini, A. (2015). Shalat Sebagai Terapi Bagi Pengidap Gangguan Kecemasan dalam PerspeKtif Psikoterapi Islam. Jurnal Bimbingan Konseling Religi, 6(2), 319-334. 
